ISSN 0258-7122

Bangladesh J. Agril. Res. 38(2): 211-217, June 2013

\title{
PERFORMANCE OF DIFFERENT HYV MUSTARD VARIETIES WITH SUGARCANE (Saccharum officinarum) AS INTERCROP IN FARMERS' FIELDS
}

\author{
M. N. ISLAM ${ }^{1}$, M. S. RAHMAN ${ }^{2}$, F. AHMED ${ }^{3}$ \\ M. S. ALOM ${ }^{1}$ AND M. AKHTERUZZAMAN ${ }^{1}$
}

\begin{abstract}
A field experiment was conducted at farmer's field of Kushtia Sadar upazila under Kushtia district during the period from November 2009 to January 2012 to find out suitable mustard varieties for intercropping with sugarcane. Five rapeseed/mustard varieties viz., Improved Tori -7, BARI Sarisha-9, BARI Sarisha-11, BARI Sarisha-14 and BARI Sarisha-15 were intercropped with sugarcane. Results showed that different intercropping combinations significantly influenced yield and yield components of mustard. The mustard variety BARI Sarisha-11 produced the highest seed yield (2199 kg/ha). Mustard varieties in intercropped situation depressed cane yields by $2.79-9.96 \%$ compared to sole cane yield. The highest cane equivalent yield (111.28 t/ha) was recorded in sugarcane + mustard var. BARI Sarisha-11 combination. The highest gross return (Tk. 633098/ha), gross margin (Tk. 518078/ha) and benefit cost ratio (5.50) were also obtained from the same combination which was followed by sugarcane + mustard var. BARI Sarisha-14 combination. The results revealed that BARI Sarisha-11 or BARI Sarisha-14 might be grown with sugarcane as intercrop in Kushtia area for getting maximum profit.
\end{abstract}

Keywords: Intercropping, HYV mustard, sugarcane, farmers’ field.

\section{Introduction}

Sugarcane (Saccharum officinarum) is one of the important cash cum industrial crop grown in allmost all districts of Bangladesh. It is a long duration crop and remains in the field for 10-14 months. So, the subsistence farmers do not want to wait for a long time to get the return from a single crop. Sugarcane is initially a slow growing crop and planted by keeping wide space in between two rows. This space remains vacant until full sugarcane canopy development providing ample chance for profuse weed growth which draws huge amount of nutrients and moisture from the soil.

Human population in Bangladesh is increasing at an alarming rate that demands more food. Therefore, to meet the demand of food viz., cereals, pulses, oilseeds, vegetables, sugar, etc. for the ever increasing population, raising production of these crops is of utmost importance. Since increasing area under

${ }^{1}$ Principal Scientific Officer, ${ }^{3}$ Senior Scientific Officer, Agronomy Division, Bangladesh Agricultural Research Institute (BARI), Gazipur and ${ }^{2}$ Senior Scientific Officer, OFRD, BARI, Kushtia, Bangladesh. 
these crops is not possible due to limited availability of agricultural land, the only option for increasing crop productivity through intercropping. Intercropping is an important tool for increasing total yield (Islam et al., 2010), higher monetary return (Begum et al., 2010) and greater resource utilization (Islam et al., 2006) as well as to fulfil the diversified need of the farmers (Akhteruzzaman et al., 2008). Besides, additional production could be realized by intercropping short duration crops with other crops like sugarcane (Malik and Kamoka, 1992). Rana et al. (2006) observed that all combination of lentil, mustard, maize, rajmash, and rapeseed with sugarcane proved more profitable than growing autumn planted cane alone. Al-Azad and Alam (2004) also found higher economic profitability from sugarcane + potato, sugarcane + onion, sugarcane + coriander, sugarcane + mustard, and sugarcane + garlic intercropping systems. Rahman et al. (1994) reported higher productivity and return in sugarcane + mustard intercropping than sugarcane sole cropping. However, sugarcane and mustard intercropping is widely practiced by the farmers in Bangladesh because they get some returns within 115 days of sowing. But the farmers use local variety of mustard as companion crop. As a result, total productivity as well as economic return is lower. Bangladesh Agricultural Research Institute has developed several high yielding mustard varieties but farmers are not acquainted with those varieties. Hence, the present study was undertaken to select suitable mustard varieties for intercropping with sugarcane having minimum adverse effect on sugarcane yield.

\section{Materials and Method}

The experiment was conducted at farmer's field of Kushtia Sadar upazila under Kushtia district during the period from November 2009 to January 2012. The soil of the experimental field was silty loam in texture with $\mathrm{pH} 7.3$ belonging to Calcareous Dark Grey Floodplain (AEZ 11). Five rapeseed/mustard varieties viz., Improved Tori -7 (Brassica campestris, rapeseed), BARI Sarisha-9 (B campestris, rapeseed), BARI Sarisha-11 (B. juncea, mustard), BARI Sarisha-14 (B. campestris, rapeseed) and BARI Sarisha-15 (B. campestris, rapeseed) were intercropped with sugarcane. Sole sugarcane was also included in this study for comparison. The experiment was laid out in a randomized complete block (RCB) design with 3 replications. The unit plot size was $6 \mathrm{~m}$ x 35m. Two to three eyed sugarcane sets of Isd 30 variety were planted on 05 November 2009 and 14 November 2010 maintaining $60 \mathrm{~cm}$ row spacing. In each case, 100\% seeds of rapeseed/mustard ( $6 \mathrm{~kg}$ seed/ha) were broadcast on the same day in between normal plantation of sugarcane $(100 \%)$. Fertilizers were applied at the rate of 220-72-240-60-8-1 kg/ha of NPKSZnB in the form of urea, TSP, MoP, Gypsum, Zinc sulphate, and Boric acid, respectively, in sole sugarcane and intercropping systems (BARC, 2005). One third of $\mathrm{N}$ and full quantity of other fertilizers were applied as basal at the time of final land preparation. The remaining $\mathrm{N}$ was top 
dressed in two equal splits at 25 days after sowing (DAS) in both the crops and 120 DAS in sugarcane only followed by irrigation. One weeding was done at 19 DAS. Aphids were controlled by spraying insecticide (Malathione) at 45 and 52 DAS. Mustard varieties Improved Tori-7 and BARI Sarisha-9 were harvested at 92 DAS; BARI Sarisha-14 and BARI Sarisha-15 at 95 DAS, while BARI Sarisha-11 at 115 DAS in both the years. Sugarcane was harvested on 29 December 2010 and 31 December 2011. Data on yield and other parameters of both the crops were recorded at the time of harvest. Plant population data for mustard varieties were taken from randomly selected three places in each plot and yield components were taken from 10 plants. Number of tillers, number of millable canes, and cane yield were taken from whole plot. Millable cane height was taken from 10 randomly selected plants. Yield data of mustard were also recorded from whole plot. Cane equivalent yield was computed by converting yield of intercrops on the basis of prevailing market price of individual crops by the formula given by Bandyopadhyay (1984). Benefit-cost analysis was also done. The data of the experiment for two consecutive years showed similar trend. So, the collected data were pooled and means were adjudged by LSD test at $5 \%$ level of significance.

\section{Results and Discussion}

Mustard: Number of siliquae/plant, seeds/siliqua, 1000-seed weight, seed yield, and stover yield/ha of different mustard varieties differed significantly under intercropping with sugarcane (Table 1). Significantly the highest number of siliquae/plant (198) was recoded in BARI Sarisha-11. The minimum number of siliquae/plant (72) was found in BARI Sarisha-14. Number of siliquae/plant is a genetically control trait but it can be changed by management manipulation like number of plants per unit area along with fertilizer application rate. BARI Sarisha-11 produced profuse branch which bears more siliquae than other varieties. This result is in agreement with the findings of Islam et al. (2011a). On the other hand, maximum number of seeds/siliqua (33.4) was observed in BARI Sarisha-14 and minimum (12.5) in BARI Sarisha-11. Intermediate number of seeds/siliqua (21.7) was found from BARI Sarisha-15. Similar results were reported by Islam et al. (2011b). BARI Sarisha-15 and BARI Sarisha-14 showed similar seed weight with bolder size, while improved Tori-7 and BARI Sarisha-9 revealed smaller seed size. Significantly the highest seed yield (2199 kg/ha) was obtained from BARI Sarisha-11. In other varieties, seed yields were identical and it ranged from 906 to $1210 \mathrm{~kg} / \mathrm{ha}$. However, lower seed yield (906 kg/ha) was recorded in Improved Tori-7. Similar trend was observed in case of stover yield/ha. These results are supported by Islam et al. (2011c). 
Table 1. Yield and yield components of mustard in sugarcane mustard intercropping systems (pooled).

\begin{tabular}{|c|c|c|c|c|c|c|}
\hline Treatments & $\begin{array}{c}\text { Plants } / \mathrm{m}^{2} \\
\text { (no.) }\end{array}$ & $\begin{array}{l}\text { Siliquae/ } \\
\text { plant } \\
\text { (no.) }\end{array}$ & $\begin{array}{l}\text { Seeds/ } \\
\text { siliqua } \\
\text { (no.) }\end{array}$ & $\begin{array}{c}1000- \\
\text { seed wt } \\
\text { (g) }\end{array}$ & $\begin{array}{c}\text { Seed } \\
\text { yield } \\
\text { (kg/ha) }\end{array}$ & $\begin{array}{l}\text { Stover } \\
\text { yield } \\
\text { (kg/ha) }\end{array}$ \\
\hline $\begin{array}{l}\text { Sugarcane + mustard } \\
\text { (var. Improved Tori-7) }\end{array}$ & 37 & 101 & 15.1 & 2.4 & 906 & 2043 \\
\hline $\begin{array}{l}\text { Sugarcane + mustard (var. } \\
\text { BARI Sarisha-9) }\end{array}$ & 35 & 122 & 16.6 & 2.6 & 1015 & 2610 \\
\hline $\begin{array}{l}\text { Sugarcane + mustard (var. } \\
\text { BARI Sarisha-11) }\end{array}$ & 36 & 198 & 12.5 & 3.1 & 2199 & 3825 \\
\hline $\begin{array}{l}\text { Sugarcane + mustard (var. } \\
\text { BARI Sarisha-14) }\end{array}$ & 30 & 72 & 33.4 & 3.2 & 1150 & 2450 \\
\hline $\begin{array}{l}\text { Sugarcane + mustard (var. } \\
\text { BARI Sarisha-15) }\end{array}$ & 34 & 96 & 21.7 & 3.4 & 1210 & 2536 \\
\hline LSD (0.05) & NS & 22 & 2.2 & 0.2 & 317 & 659 \\
\hline CV (\%) & 12 & 10 & 6 & 4 & 13 & 13 \\
\hline
\end{tabular}

NS= Not significant

\section{Sugarcane}

Millable cane height, number of tillers, number of millabale canes, cane yield, and dry leaves yield of canes/ha showed non-significant effect due to intercropping with different mustard varieties (Table 2). However, number of tillers/ha and number of millabale canes/ha were decreased more compared to sole sugarcane where BARI Sarisha-11 was intercropped with sugarcane (i.e. values were the lowest), which is in close conformity with the findings of Muhammad et al. (2000). These results happened possibly due to more competition of sugarcane with companion crops for nutrients and moisture, which may cause lower emergence of tiller and formation of canes. BARI Sarisha-11 also shaded the cane shoots in the early period of growth, restricting light for development of cane, as such tillering was reduced leading to low cane formation. This result is in agreement with the findings of Malik and Kamoka (1992). Intercropping of mustard varieties decreased cane yields by 2.79 to 9.96\% over sole sugarcane (Table 2). Maximum yield reduction (9.96\%) of cane was recorded where BARI Sarisha-11 was grown which might be occurred due to more competition for growth resources and long duration. In case of other mustard varieties, yield reduction of cane varied depending on degree of competition. Minimum yield reduction (2.79\%) was observed where improved Tori-7 was grown and this might be happened due to its short duration and lesser canopy coverage. Similar results were reported by Singh et al. (1986). 
Table 2. Yield and yield components of sugarcane in sugarcane mustard intercropping systems (pooled).

\begin{tabular}{|c|c|c|c|c|c|c|}
\hline Treatments & $\begin{array}{l}\text { Millable } \\
\text { cane } \\
\text { height } \\
(\mathrm{cm})\end{array}$ & $\begin{array}{c}\text { Tiller x } \\
\text { ‘000’/ha } \\
\text { (no.) }\end{array}$ & $\begin{array}{c}\text { Millable } \\
\text { canes x } \\
\text { ‘000’/ha } \\
\text { (no.) }\end{array}$ & $\begin{array}{l}\text { Cane } \\
\text { yield } \\
\text { (t/ha) }\end{array}$ & $\begin{array}{c}\text { Dry } \\
\text { leaves } \\
\text { yield } \\
\text { (t/ha) }\end{array}$ & $\begin{array}{c}\text { Cane yield } \\
\text { reduction } \\
\text { over sole } \\
(\%)\end{array}$ \\
\hline $\begin{array}{l}\text { Sugarcane }+ \text { mustard } \\
\text { (var. Improved Tori-7) }\end{array}$ & 436 & 82.41 & 75.07 & 102.01 & 11.15 & 2.79 \\
\hline $\begin{array}{l}\text { Sugarcane + mustard (var. } \\
\text { BARI Sarisha-9) }\end{array}$ & 411 & 78.52 & 69.14 & 95.81 & 9.97 & 8.70 \\
\hline $\begin{array}{l}\text { Sugarcane + mustard (var. } \\
\text { BARI Sarisha-11) }\end{array}$ & 405 & 77.27 & 68.90 & 94.49 & 8.93 & 9.96 \\
\hline $\begin{array}{l}\text { Sugarcane + mustard (var. } \\
\text { BARI Sarisha-14) }\end{array}$ & 427 & 80.12 & 73.03 & 100.62 & 10.58 & 4.12 \\
\hline $\begin{array}{l}\text { Sugarcane + mustard (var. } \\
\text { BARI Sarisha-15) }\end{array}$ & 417 & 79.39 & 70.58 & 98.39 & 10.25 & 6.24 \\
\hline Sole sugarcane & 440 & 83.94 & 77.11 & 104.94 & 11.97 & - \\
\hline $\operatorname{LSD}(0.05)$ & NS & NS & NS & NS & NS & - \\
\hline CV (\%) & 9 & 6 & 6 & 11 & 12 & - \\
\hline
\end{tabular}

NS= Not significant

\section{Intercrop efficiency}

Cane equivalent yield (CEY) and benefit cost analyses are presented in Table 3. All the intercrop combination produced higher CEY over sole cane yield except Sugarcane + BARI Sarisha-9 combination. Among those, the highest CEY (111.28 t/ha) was recorded in Sugarcane + BARI Sarisha-11 combination which was very close to Sugarcane + BARI Sarisha-14 combination (109.40 t/ha). Maximum CEY in aforesaid combination was observed mainly for the highest seed yield of BARI Sarisha-11. The highest gross return (Tk. 633098/ha) was obtained from Sugarcane with BARI Sarisha-11 combination might be for the highest stover yield of BARI Sarisha-11. Cost of production of sugarcane and mustard intercropping systems was more than sole sugarcane because of the involvement of mustard seed cost as well as cost of more labours engaged in intercultural operations. The highest gross margin (Tk. 518078/ha) was found from sugarcane with BARI Sarisha-11 combination which was very close to sugarcane with BARI Sarisha-14 combination owing to higher gross returns. The highest benefit cost ratio (5.50) was recorded in sugarcane + BARI Sarisha-11 combination and it was also very close to sugarcane with BARI Sarisha-14 combination (5.41). Nayyar et al. (1987) also obtained higher CEY and economic returns from intercropping of some field and garden crops with sugarcane. 
Table 3. Cane equivalent yield and benefit cost analysis of sugarcane mustard intercropping systems (averaged).

\begin{tabular}{l|c|c|c|c|c}
\hline \multicolumn{1}{c|}{ Treatments } & $\begin{array}{c}\text { Cane } \\
\text { equivalent } \\
\text { yield (t/ha) }\end{array}$ & $\begin{array}{c}\text { Gross } \\
\text { return* } \\
\text { (Tk./ha) }\end{array}$ & $\begin{array}{c}\text { Total cost of } \\
\text { production** } \\
\text { (Tk./ha) }\end{array}$ & $\begin{array}{c}\text { Gross } \\
\text { margin } \\
\text { (Tk./ha) }\end{array}$ & $\begin{array}{c}\text { Benefit } \\
\text { cost ratio }\end{array}$ \\
\hline $\begin{array}{l}\text { Sugarcane + mustard } \\
\text { (var. Improved Tori-7) }\end{array}$ & 108.93 & 619918 & 115020 & 504898 & 5.39 \\
$\begin{array}{l}\text { Sugarcane + mustard } \\
\text { (var. BARI Sarisha-9) }\end{array}$ & 103.56 & 589760 & 115020 & 474740 & 5.13 \\
$\begin{array}{l}\text { Sugarcane + mustard } \\
\text { (var. BARI Sarisha-11) }\end{array}$ & 111.28 & 633098 & 115020 & 518078 & 5.50 \\
$\begin{array}{l}\text { Sugarcane + mustard } \\
\text { (var. BARI Sarisha-14) }\end{array}$ & 109.40 & 622480 & 115020 & 507460 & 5.41 \\
$\begin{array}{l}\text { Sugarcane + mustard } \\
\text { (var. BARI Sarisha-15) }\end{array}$ & 107.63 & 612412 & 115020 & 497392 & 5.32 \\
\begin{tabular}{l} 
Sole sugarcane \\
\hline
\end{tabular} & 104.94 & 595125 & 114720 & 480405 & 5.19 \\
\hline
\end{tabular}

* Includes return from cane, mustard seed, mustard stover and dry leaves of sugarcane Market price (Tk./kg):- mustard seed: 42.00, stover: 2.00, cane: 5.50 and dry leaf: 1.50

** Includes cost of land preparation, seeds, fertilizers, insecticides, irrigation and labours

The results revealed that sugarcane + BARI Sarisha-11 or BARI Sarisha-14 combination was the most productive and profitable than other combinations in Kushtia area. So, the farmers of sugarcane growing areas could be suggested to grow mustard (var. BARI Sarisha-11 or BARI Sarisha-14) as intercrop with sugarcane for getting maximum profit.

\section{References}

Akhteruzzaman, M., M. N. Islam, B. L. Nag and M. T. Rahman. 2008. Productivity of potato-hybrid maize relay cropping under different fertilizer levels. Eco-friendly Agril. J. 1(5):300-303.

Al-Azad, M. A. K. and M. J. Alam. 2004. Popularizing of sugarcane based intercropping systems in non mill zone. J. Agron. 3(3): 159-161.

Bandyopadhyay, S. N. 1984. Nitrogen and water relations in grain sorghum-legume intercropping systems. Ph.D. Dissertation, Indian Agricultural Research Institute, New Delhi.

BARC (Bangladesh Agricultural Research Council). 2005. Fertilizer recommendation guide-2005. Bangladesh Agricultural Research Council, Farmgate, New Airport Road, Dhaka-1215.

Begum, S., M. N. Islam, M. T. Rahman, J. A. Chowdhury and M. I. Haque. 2010. Suitability study of different chili varieties for intercropping with sweet gourd. $J$. Expt. Biosci. 1(2): 1-4. 
Islam, M. N., M. M. Haque and A. Hamid. 2006. Planting arrangement and population density effects on the physiological attributes and productivity of maize-bushbean intercropping systems. Bangladesh J. Agril. Res. 31(3):353-364

Islam, M. N., F. Ahmed and M. A. Hossain. 2011b. Adaptive trial of different HYV crop varieties at charland under different agro-ecological zones of Bangladesh. Bangladesh Agron. J. 14 (1 \& 2): 67-75.

Islam, M. N., M. Akhteruzzaman, F. Ahmed, M. S. A. Khan and S. Begum. 2011a. Performance of mustard, lentil and hybrid maize varieties in charland of Kushtia district. J. Expt. Biosci. 2(1): 01-04.

Islam, M. N., M. A. I. Sarker, M. K. Islam, S. Begum and M. A. Mannaf. 2010. Intercropping of brinjal with chili under different planting geometry for higher productivity and return. J. Expt. Biosci. 1(2): 51-55.

Islam, M. N., F. Ahmed, M. S. A. Khan and W. Sultana. 2011c. Varietal trial of HYV mustard at newly developed charland. In charland research 2007-2010, Agronomy Division, Bangladesh Agricultural Research Institute, Joydebpur, Gazipur. pp. 01-04.

Malik, K. B. and M. N. Kamoka. 1992. Agro-economic study of intercropping potato and raya in autumn crop of sugarcane. Pakistan J. Agric. Res. 13(2): 126-131.

Muhammad, I. S. I. M. Ayaz and I. Ahmad. 2000. A Glance at the agronomic study of sugarcane intercropping with three other crops. Pak. Sugar. J. 15: 18-22.

Nayyar, M. M., K. B. Malik, M. N. Kamoka and M. A. Gill. 1987. Economic feasibility of intercropping some field and garden crops in spring and autumn crop of sugarcane. Proc. Pakistan Soc.S. Tech. 23: 107-122.

Rahman, M. S., M. F. Haq, M. S. Islam, M. K. Bashar, N. Ara and P. K. Sardar. 1994. Sugarcane based intercropping in selected areas of Rajshahi sugar mill zone. Bangladesh J. Sugarcane. 16: 44-48.

Rana, N. S., K. Sanjay, S. K. Saini and G. S. Panwar. 2006. Production potential and profitability of autumn sugarcane based intercropping systems as influenced by intercrops and row spacing. Indian J. Agron. 51(1): 31-33.

Singh, V., S. K. Kothari and H. N. Tripathi. 1986. Studies on intercropping in sugarcane in Central Uttar Pradesh. Ind. Sug. J. 35(10): 559-562. 